\title{
Aqueous Phase Methylation as a Potential Source of Methylmercury in Wet Deposition
}

Chad R. Hammerschmidt*,a, Carl H. Lamborg ${ }^{\mathrm{a}}$, William F. Fitzgerald ${ }^{\mathrm{b}}$

${ }^{a}$ Department of Marine Chemistry and Geochemistry, Woods Hole Oceanographic

Institution, Woods Hole, MA, USA

${ }^{b}$ Department of Marine Sciences, University of Connecticut, Groton, CT, USA.

*Corresponding author. Department of Marine Chemistry and Geochemistry, Woods

Hole Oceanographic Institution, MS \#51, Woods Hole, MA, USA 02543.

E-mail: methylhg@whoi.edu (C. R. Hammerschmidt)

Tel: 508-289-3551

Fax: 508-457-2075 


\begin{abstract}
The source of monomethylmercury (MMHg) in wet deposition is unknown.

Volatilization of gaseous MMHg, evasion and demethylation of dimethylmercury, and methylation of $\mathrm{Hg}^{0}$ have been either proposed or tested unsuccessfully as potential sources. Here, we show that MMHg in precipitation, sampled across a wide geographical range in North America, is related positively to an operationally defined and measured reactive $\mathrm{Hg}$ species $\left(\mathrm{Hg}_{\mathrm{R}}\right)$, but connected weakly to total $\mathrm{Hg}$. The mean molar ratio of MMHg: $\mathrm{Hg}_{\mathrm{R}}$ measured in continental precipitation $(0.025 \pm 0.006)$ is comparable to the MMHg:Hg(II) ratio estimated from first-order rate constants for acetate-mediated Hg methylation and MMHg photolysis (0.025 \pm 0.002$)$. This suggests MMHg may be formed in the atmosphere through a reaction between labile Hg(II) complexes and an unknown methylating agent(s), potentially acetate or similar molecules. Availability of Hg(II) appears to limit the reaction, and accordingly, increased atmospheric loadings of Hg could lead to enhanced MMHg in precipitation.
\end{abstract}

Keywords: mercury; abiotic; atmosphere; precipitation; photodecomposition 


\section{Introduction}

Precipitation often contains trace quantities of monomethylmercury (MMHg), the toxic and bioaccumulative form of Hg; however, the source of the MMHg in wet deposition is unknown (Downs et al., 1998). Most MMHg in the environment is presumed to result from methylation of inorganic Hg complexes (Hg(II)) by microorganisms, notably sulfate-reducing (Benoit et al., 2003) and iron-reducing bacteria (Fleming et al., 2006). Given that the atmospheric environment is relatively inhospitable for anaerobic bacteria, mechanisms other than in situ microbial production have been either proposed or tested as potential sources of MMHg in precipitation. These include volatilization of $\mathrm{CH}_{3} \mathrm{Hg}$ complexes from surface waters (Mester and Sturgeon, 2002) and landfills (Lindberg et al., 2001), oceanic evasion and subsequent demethylation of dimethylmercury (DMHg; Bloom et al., 1996; St. Louis et al., 2005), gas-phase methylation of elemental $\mathrm{Hg}\left(\mathrm{Hg}^{0}\right)$ by methyl carbonium and/or methyl radical donors (Hall et al., 1995), and aqueous-phase methylation of Hg(II) in the atmosphere (Gårdfeldt et al., 2003).

Laboratory studies have shown a considerable potential for abiotic methylation of Hg(II) exists in the environment. These include observations of artifact MMHg formation from $\mathrm{Hg}(\mathrm{II})$ during extraction or analysis of sediments, biota, and natural waters (Bloom et al., 1997; Holz et al., 1999; Hammerschmidt and Fitzgerald, 2001), and positive results for wet-chemical Hg(II) methylation tests with acetate (Akagi and Takabatake, 1973; Bloom et al., 1997; Gårdfeldt et al., 2003), organic acids with a methyl group in the $\forall$-position (Falter, 1999), other methylated metals (Howell et al., 1986; Cerrati et al., 1992), and humic substances (Weber, 1993). It has been hypothesized that 
labile $\mathrm{Hg}(\mathrm{II})$ complexes, commonly assayed as reactive $\mathrm{Hg}\left(\mathrm{Hg}_{\mathrm{R}}\right)$, are a substrate for abiotic and biological reactions that produce both $\mathrm{Hg}^{0}$ and methylated forms of $\mathrm{Hg}$ in aquatic systems (Mason and Fitzgerald, 1990; Fitzgerald et al., 1991). $\mathrm{Hg}_{\mathrm{R}}$ is an operationally defined fraction of $\mathrm{Hg}$ that is reduced readily with $\mathrm{SnCl}_{2}$ at low $\mathrm{pH}$, and includes weak organic associations, inorganic complexes, and labile particulate Hg (Mason and Fitzgerald, 1990). While the thermodynamic and kinetic interpretation of the $\mathrm{Hg}_{\mathrm{R}}$ determination can vary among environmental matrixes (Bloom, 1994; Lamborg et al., 2003), we have observed positive relationships between $\mathrm{Hg}_{\mathrm{R}}$ and both $\mathrm{Hg}^{0}$ in estuarine water (Rolfhus and Fitzgerald, 2001) and MMHg produced abiotically in extracts of marine sediment (Hammerschmidt and Fitzgerald, 2001). We submit that levels of strong Hg-binding organic ligands are low enough in aqueous environments of the atmosphere (cloudwater, liquid phases, or aerosols) so that all Hg(II) present in solution will be associated with complexing agents that are kinetically facile, and therefore able to exchange rapidly with other ligands in accordance with dynamic equilibrium. Thus, solid-solution partitioning of $\mathrm{Hg}(\mathrm{II})$ in atmospheric water should be the primary control on Hg "reactivity” (Mason et al., 1997). Accordingly, and if aqueous methylation of labile Hg(II) complexes were an important source of MMHg, then a positive relationship would be expected between $\mathrm{MMHg}$ and $\mathrm{Hg}_{\mathrm{R}}$ in precipitation.

\section{Hg Speciation in Precipitation}

Figure 1 shows that mean concentrations of $\mathrm{MMHg}$ and $\mathrm{Hg}_{\mathrm{R}}$ in wet deposition are correlated strongly among a variety of locations spanning North America. This relationship is based on values reported in the peer-reviewed literature (Table 1), which 
contains limited information on $\mathrm{Hg}_{\mathrm{R}}$ in precipitation. However, and although average levels of MMHg and $\mathrm{Hg}_{\mathrm{R}}$ vary widely within and among locations/studies (Table 1), there is a relatively constant degree of proportionality between mean concentrations of the two Hg species (Fig. 1). The mean molar ratio of MMHg: $\mathrm{Hg}_{\mathrm{R}}$ is $0.025 \pm 0.006$ among continental locations (Table 1). The relatively consistent ratio between MMHg and $\mathrm{Hg}_{\mathrm{R}}$ suggests that either these two $\mathrm{Hg}$ species have comparable atmospheric behavior or that $\mathrm{Hg}_{\mathrm{R}}$ is a substrate for $\mathrm{MMHg}$ and a molar ratio of about 0.025 represents a steadystate condition between competing methylation and demethylation reactions.

If $\mathrm{Hg}_{\mathrm{R}}$ were a substrate for $\mathrm{MMHg}$, then one would not expect MMHg to be related to total $\mathrm{Hg}$ (sum of all $\mathrm{Hg}$ species including $\mathrm{Hg}_{\mathrm{R}}$ ) in precipitation, given that the fraction of total $\mathrm{Hg}$ as $\mathrm{Hg}_{\mathrm{R}}$ in wet deposition is highly variable, ranging from $14 \%$ to $95 \%$ (Table 1). Figure 2 shows a weak relationship $\left(r^{2}=0.26, p=0.09\right)$ between mean concentrations of MMHg and total $\mathrm{Hg}$ in precipitation among the same samples shown in Figure 1, as well as several other studies that did not assay $\mathrm{Hg}_{\mathrm{R}}$. It appears that MMHg in precipitation is more a function of $\mathrm{Hg}_{\mathrm{R}}$ (Fig. 1) than of total $\mathrm{Hg}$ (Fig. 2). Sorption to particles plays a major role in determining the "reactivity" of $\mathrm{Hg}$ in precipitation (Mason et al., 1997), and thereby, may control the fraction of total Hg that is available for methylation reactions.

\section{Potential Sources of MMHg}

If volatilization and dissolution of gaseous $\mathrm{CH}_{3} \mathrm{Hg}$ species, including those derived from oceanic evasion and atmospheric demethylation of DMHg, were the primary source of MMHg in precipitation, then, on average, these processes must 
proceed at rates that are proportional to those affecting the formation and removal of $\mathrm{Hg}_{\mathrm{R}}$ in order to the explain the relationship between $\mathrm{MMHg}$ and $\mathrm{Hg}_{\mathrm{R}}$ in Figure $1 . \mathrm{Hg}_{\mathrm{R}}$ in precipitation, largely ionic $\mathrm{Hg}(\mathrm{II})$ (Mason et al., 1992), is emitted from natural and anthropogenic sources (Nacht et al., 2004; Lee et al., 2006) and produced by atmospheric oxidation of $\mathrm{Hg}^{0}$ (Fogg and Fitzgerald, 1979), the rate of which varies spatially depending on the strength and abundance of atmospheric oxidants (Fitzgerald and Lamborg, 2003). Hg(II) is scavenged by particles (Lamborg et al., 2000), and as noted, levels of $\mathrm{Hg}_{\mathrm{R}}$ in precipitation are highly dependent on the concentration and nature of particulate material. Accordingly, it is unlikely that gas-phase concentrations and dissolution of MMHg complexes are comparable to unrelated processes affecting $\mathrm{Hg}_{\mathrm{R}}$, especially given the heterogeneity of $\mathrm{Hg}(\mathrm{II})$ emissions, $\mathrm{Hg}^{0}$ oxidation, and $\mathrm{Hg}(\mathrm{II})$ scavenging. However, and although accurate measurements of gaseous MMHg species in the atmosphere limit our understanding of its distribution and equilibrium with precipitation (Bloom and Watras, 1989), the potential significance of this process can be evaluated in oceanic upwelling regions where atmospheric concentrations of DMHg should be greatest.

DMHg appears to be produced throughout the oceanic water column. Enhanced DMHg levels, for example, have been observed in low-oxygen subsurface waters of the equatorial Atlantic and Pacific Oceans as well as in recently formed deep waters of the Atlantic (Mason and Fitzgerald, 1990; Mason and Sullivan, 1999). Levels in the surface mixed layer usually are not measurable (<0.005-0.015 pM; Mason and Fitzgerald, 1990; Mason et al., 1995; Mason and Sullivan, 1999), and this has been attributed principally to demethylation in surface water rather than atmospheric evasion (Mason and Fitzgerald, 
1993). Thus, DMHg must be transported rapidly to the surface for it to escape to the atmosphere. If DMHg from subsurface waters were an important source of MMHg in precipitation, then the concentrations should be elevated near the equator, where rates of upwelling are substantial and DMHg, as noted, is enhanced in sub-thermocline waters (Mason et al., 1990; Mason and Sullivan, 1999). However, no detectable amounts of MMHg ( $<0.05$ pM) were present in equatorial Pacific rain (Mason et al., 1992), and only one of five rain samples from the equatorial Atlantic had levels exceeding a detection limit of 0.04 pM (Table 1; Lamborg et al., 1999). MMHg in equatorial oceanic rain is much less than that in precipitation over the North American continent (Table 1), and these results suggest that DMHg evasion is not an important source of MMHg in wet deposition at most locations. Moreover, and if MMHg in precipitation results from methylation of $\mathrm{Hg}_{\mathrm{R}}$ (Figure 1), then it is possible that the responsible methylating agent(s) may be terrestrially derived. Although all oceanic rain samples contained ample $\mathrm{Hg}_{\mathrm{R}}$ (Table 1), only one, as noted, had a detectable quantity of MMHg, and the composition of this sample was influenced by continental air from western Africa, as evidenced by the amounts of $\mathrm{Al}$ and Fe (Lamborg et al., 1999). An alternative explanation for exceedingly low levels of MMHg in oceanic rain is that its decomposition is enhanced in the marine troposphere, potentially by reactive halogens (Sheu and Mason, 2004) that readily demethylate MMHg (Hammerschmidt and Fitzgerald, 2001).

The mean MMHg:Hg molar ratio of 0.025 in continental precipitation (Table 1) is consistent with results from kinetic experiments of MMHg photochemical decomposition (Gårdfeldt et al., 2001) and production from acetate (Gårdfeldt et al., 
2003) in simulated natural waters. We hypothesize that MMHg in precipitation results from competing methylation and demethylation reactions with $\mathrm{Hg}(\mathrm{II})$ such that

$$
\frac{d M M H g}{d t}=k_{\text {meth }}[H g(I I)][M A]-k_{\text {demeth }} h v[M M H g]
$$

where $k_{m e t h}$ and $k_{\text {demeth }}$ respectively are methylation and demethylation rate constants, $h v$ is solar radiation, and $M A$ is a methylating agent(s). Gårdfeldt and colleagues (2003) have shown that acetate is a prolific methylator of $\mathrm{Hg}(\mathrm{II})$ in simulated rainwater (i.e., dilute, $\mathrm{pH}$ 4.9), and that the gross rate of MMHg production is pseudo-first order with respect to $\mathrm{Hg}(\mathrm{II})$ concentration and independent of light. Accordingly, and assuming that 1) $M A$ is available in excess relative to $\mathrm{Hg}(\mathrm{II})$, which is reasonable given that levels of acetate in the atmospheric aqueous phase (1-10 $\mu \mathrm{M}$; Chebbi and Carlier, 1996; Kieber et al., 2002) are $10^{5}-10^{6}$ greater than $\mathrm{Hg}_{\mathrm{R}}$ (Table 1), and 2) demethylation is mostly a function of MMHg concentration (Gårdfeldt et al., 2001; Hammerschmidt and Fitzgerald, 2006), then Equation 1 can be simplified to a steady-state expression where $[M M H g]_{s s} /[H g(I I)]_{s s}=k_{m e t h} / k_{d e m e t h}$. Gårdfeldt and co-workers (2001) determined $k_{\text {demeth }}=$ $2.2( \pm 0.2) \times 10^{-4} \mathrm{~s}^{-1}$ in synthetic rainwater irradiated with filtered light $(\lambda>290 \mathrm{~nm})$ from a collimated $450 \mathrm{~W}$ Xe lamp at $0.45 \mathrm{~m}$ (Katarina Gårdfeldt, personal communication). The shortwave (300-5000 nm) light exposure of samples in these tests ( $140 \mathrm{~W} \mathrm{~m}^{-2}$ ) is comparable to the average shortwave solar insolation at Earth’s surface (165 $\mathrm{W} \mathrm{m}^{-2}$; Rossow and Zhang, 1995) and within a factor of two of the flux into the top of the atmosphere (230 $\mathrm{W} \mathrm{m}^{-2}$; Rossow and Zhang, 1995). Thus, and with a laboratorymeasured $k_{\text {meth }}$ of $5.4 \times 10^{-6} \mathrm{~s}^{-1}$ for $\mathrm{Hg}(\mathrm{II})$ and acetate in artificial rainwater (Gårdfeldt et al., 2003), the expected steady-state MMHg:Hg(II) ratio in precipitation would be 0.025 
\pm 0.002 . The uncertainty associated with this estimate results from variability in the

$k_{\text {demeth }}$ determination only; no uncertainty was reported for $k_{\text {meth }}$. The estimated steadystate MMHg:Hg(II) molar ratio is comparable to that approached after 325 min incubation of $\mathrm{Hg}(\mathrm{II})$ in the presence of acetate under irradiation from the Xe lamp (about 0.025; Fig. 4 in Gårdfeldt et al., 2003), and most noteworthy, similar to the average MMHg: $\mathrm{Hg}_{\mathrm{R}}$ concentration ratio measured in North American precipitation (0.025 \pm 0.006; Table 1).

\section{Conclusions}

MMHg in North American precipitation is related to $\mathrm{Hg}_{\mathrm{R}}$, an operationally defined fraction of $\mathrm{Hg}$ that includes mostly labile $\mathrm{Hg}(\mathrm{II})$ complexes. Mean MMHg: $\mathrm{Hg}_{\mathrm{R}}$ molar ratios in wet deposition are similar among sampling locations and periods on the continent, and comparable to the steady-state condition predicted from laboratorydetermined rate constants for sunlight-mediated MMHg photodecomposition and $\mathrm{Hg}(\mathrm{II})$ methylation by acetate. This suggests that MMHg in precipitation may be formed by an aqueous phase methylation reaction involving $\mathrm{Hg}(\mathrm{II})$, although it is unknown whether acetate is the responsible methylating agent. Levels of acetate far exceed those of $\mathrm{Hg}_{\mathrm{R}}$ in both continental and marine atmospheres, implying that $\mathrm{Hg}(\mathrm{II})$ should limit the methylation reaction and a positive relationship between $\mathrm{MMHg}$ and $\mathrm{Hg}_{\mathrm{R}}$ might be expected. Solid-solution partitioning of $\mathrm{Hg}$ may be the primary control on $\mathrm{Hg}_{\mathrm{R}}$ in aqueous environments of the atmosphere, given that dissolved $\mathrm{Hg}(\mathrm{II})$ will be associated with complexing agents that are kinetically facile, and therefore able to exchange rapidly with other ligands ( $\mathrm{t}_{1 / 2}<3 \mathrm{~h}$; Lamborg et al., 2003), relative to the methylation reaction 
( $\mathrm{t}_{1 / 2}=36$ h; Gårdfeldt et al., 2003), in accordance with dynamic equilibrium. Thus, and if MMHg in precipitation were produced from $\mathrm{Hg}_{\mathrm{R}}$ in the atmosphere, then changes in atmospheric Hg and/or particle loadings should result in a corresponding increase or decline in the net synthesis and deposition of MMHg.

\section{Acknowledgments}

We are grateful to Katarina Gårdfeldt for helpful comments on an earlier draft of the manuscript. This study was supported by a grant from the National Science FoundationOffice of Polar Programs (0425562) and the Postdoctoral Scholar Program at the Woods Hole Oceanographic Institution, with funding from the Doherty Foundation.

\section{References}

Akagi, H., Takabatake, E., 1973. Photochemical formation of methylmercuric compounds from mercuric acetate. Chemosphere 3, 131-133.

Balcom, P. H., Fitzgerald, W. F., Vandal, G. M., Lamborg, C. H., Rolfhus, K. R., Langer, C. S., Hammerschmidt, C. R., 2004. Mercury sources and cycling in the Connecticut River and Long Island Sound. Marine Chemistry 90, 53-74.

Benoit, J. M., Gilmour, C. C., Heyes, A., Mason, R. P., Miller, C. L., 2003. Geochemical and biological controls over methylmercury production and degradation in aquatic ecosystems, in: Cai, Y., Braids, O. C. (Eds.), Biogeochemistry of Environmentally Important Trace Metals, American Chemical Society, Washington, D.C., pp. 262-297. 
Bloom, N. S., 1994. Influence of analytical conditions on the observed "reactive mercury” concentration in natural freshwaters, in: Watras, C. J., Huckabee, J. W. (Eds.), Mercury Pollution: Integration and Synthesis, Lewis, Boca Raton, pp. $541-552$.

Bloom, N. S., Watras, C. J., 1989. Observations of methylmercury in precipitation. The Science of the Total Environment 87/88, 199!207.

Bloom, N. S., Prestbo, E., von der Geest, E., Kuhn, E. S., 1996. Distribution and origins of mercury species in the Pacific Northwest atmosphere. Paper presented at $4^{\text {th }}$ International Conference on Mercury as a Global Pollutant, Hamburg, Germany.

Bloom, N. S., Colman, J. A., Barber, L., 1997. Artifact formation of methyl mercury during aqueous distillation and alternative techniques for the extraction of methyl mercury from environmental samples. Fresenius’ Journal of Analytical Chemistry 358, 371!377.

Cerrati, G., Bernhard, M., Weber, J., 1992. Model reactions for abiotic mercury(II) methylation: Kinetics of methylation of mercury(II) by mono-, di-, and trimethyltin in seawater. Applied Organometallic Chemistry 6, 587!595.

Chebbi, A., Carlier, P., 1996. Carboxylic acids in the troposphere, occurrence, sources, and sinks: A review. Atmospheric Environment 30, 4233!4249.

Downs, S. G., MacLeod, C. L., Nester, J. N., 1998. Mercury in precipitation and its relation to bioaccumulation in fish: A literature review. Water, Air, and Soil Pollution 108, $149 ! 187$.

Falter, R., 1999. Experimental study on the unintentional abiotic methylation of inorganic mercury during analysis: Part 2: Controlled laboratory experiments to 
elucidate the mechanism and critical discussion of the species specific isotope addition correction method. Chemosphere 39, 1075!1091.

Fitzgerald, W. F., Lamborg, C. H., 2003. Geochemistry of mercury in the environment, in: Lollar, B. S. (Ed.), Treatise on Geochemistry, Volume 9, Elsevier, Amsterdam, pp. 107-148.

Fitzgerald, W. F., Mason, R. P., Vandal, G. M., 1991. Atmospheric cycling and air-water exchange of mercury over mid-continental lacustrine regions. Water, Air, and Soil Pollution 56, $745 ! 767$.

Fleming, E. J., Mack, E. E., Green, P. G., Nelson, D. C., 2006. Mercury methylation from unexpected sources: Molybdate-inhibited freshwater sediments and an ironreducing bacterium. Applied and Environmental Microbiology 72, 457-464.

Fogg, T. R., Fitzgerald, W. F., 1979. Mercury in southern New England rains. Journal of Geophysical Research 84, 6987-6988.

Gårdfeldt, K., Sommar, J., Strömberg, D., Feng, X., 2001. Oxidation of atomic mercury by hydroxyl radicals and photoinduced decomposition of methylmercury species in the aqueous phase. Atmospheric Environment 35, 3039-3047.

Gårdfeldt, K., Munthe, J., Strömberg, D., Lindqvist, O., 2003. A kinetic study on the abiotic methylation of divalent mercury in the aqueous phase. The Science of the Total Environment 304, 127-136.

Hall, B., Bloom, N. S., Munthe, J., 1995. An experimental study of two potential methylation agents of mercury in the atmosphere: $\mathrm{CH}_{3} \mathrm{I}$ and DMS. Water, Air, Soil Pollution 80, 337-341. 
Hammerschmidt, C. R., Fitzgerald, W. F., 2001. Formation of artifact methylmercury during extraction from a sediment reference material. Analytical Chemistry 73, $5930 ! 5936$.

Hammerschmidt, C. R., Fitzgerald, W. F., 2006. Photodecomposition of methylmercury in an arctic Alaskan lake. Environmental Science \& Technology 40, 1212-1216.

Holz, J., Kreutzmann, J., Wilken, R.-D., Falter, R., 1999. Methylmercury monitoring in rainwater samples using in situ ethylation in combination with GC-AFS and GCICP-MS techniques. Applied Organometallic Chemistry 13, 789-794.

Howell, G. N., O’Connor, M. J., Bond, A. M., Hudson, H. A., Hanna, P. J., Strother, S., 1986. Methylmercury generation in seawater by transmethylation reactions of organo-lead and -tin compounds with inorganic mercury as monitored by multinuclear magnetic resonance and electrochemical techniques. Australian Journal of Chemistry 39, 1167!1175.

Kieber, R. J., Peake, B., Willey, J. D., G. B. Avery, 2002. Dissolved organic carbon and organic acids in coastal New Zealand rainwater. Atmospheric Environment 36, $3557-3563$.

Lamborg, C. H., Fitzgerald, W. F., Vandal, G. M., Rolfhus, K. R., 1995. Atmospheric mercury in northern Wisconsin: Sources and species. Water, Air, and Soil Pollution 80, 189-198.

Lamborg, C. H., Rolfhus, K. R., Fitzgerald, W. F., Kim, G., 1999. The atmospheric cycling and air-sea exchange of mercury species in the South and equatorial Atlantic Ocean. Deep-Sea Research Part II 46, $957 ! 977$. 
Lamborg, C. H., Fitzgerald, W. F., Graustein, W. C., Turekian, K. K., 2000. An examination of the atmospheric chemistry of mercury using ${ }^{210} \mathrm{~Pb}$ and ${ }^{7} \mathrm{Be}$. Journal of Atmospheric Chemistry 36, 325!338.

Lamborg, C. H., Tseng, C.-M., Fitzgerald, W. F., Balcom, P. H., Hammerschmidt, C. R., 2003. Determination of the mercury complexation characteristics of dissolved organic matter in natural waters with "reducible Hg” titrations. Environmental Science \& Technology, 37, 3316-3322.

Lee, S. J., Seo, Y.-C., Jang, H.-N., Park, K.-S., Baek, J.-I., An, H.-S., Song, K.-C., 2006. Speciation and mass distribution of mercury in a bituminous coal-fired power plant. Atmospheric Environment 40, 2215-2224.

Lindberg, S. E., Wallschläger, D., Prestbo, E. M., Bloom, N. S., Price, J., Reinhart, D., 2001. Methylated mercury species in municipal waste landfill gas sampled in Florida, USA. Atmospheric Environment 35, 4011-4015.

Mason, R. P., Fitzgerald, W. F., 1990. Alkylmercury species in the equatorial Pacific. Nature 347, 457!459.

Mason, R. P., Fitzgerald, W. F., 1993. The distribution and biogeochemical cycling of mercury in the equatorial Pacific Ocean. Deep-Sea Research Part I 40, $1897 ! 1924$.

Mason, R. P., Sullivan, K. A., 1999. The distribution and speciation of mercury in the South and equatorial Atlantic. Deep-Sea Research Part II 46, 937-956.

Mason, R. P., Fitzgerald, W. F., Vandal, G. M., 1992. The sources and composition of mercury in Pacific Ocean rain. Journal of Atmospheric Chemistry 14, $489 ! 500$. 
Mason, R. P., Rolfhus, K. R., Fitzgerald, W. F., 1995. Methylated and elemental mercury cycling in surface and deep ocean waters of the North Atlantic. Water, Air, and Soil Pollution 80, 665!677.

Mason, R. P., Lawson, N. M., Sullivan, K. A., 1997. The concentration, speciation and sources of mercury in Chesapeake Bay precipitation. Atmospheric Environment 31, $3541 ! 3550$.

Mester, Z., Sturgeon, R. E., 2002. Detection of volatile organometal chloride species in model atmosphere above seawater and sediment. Environmental Science \& Technology 36, 1198-1201.

Nacht, D. M., Gustin, M. S., Engle, M. A., Zehner, R. E., Giglini, A. D., 2004. Atmospheric mercury emissions and speciation at the Sulphur Bank Mercury Mine Superfund site, northern California. Environmental Science \& Technology 38, 1977-1983.

Rolfhus, K. R., Fitzgerald, W. F., 2001. The evasion and spatial/temporal distribution of mercury species in Long Island Sound, CT-NY. Geochimica et Cosmochimica Acta 65, 407-418.

Rossow, W. B., Zhang, Y.-C., 1995. Calculation of surface and top of atmosphere radiative fluxes from physical quantities based on ISCCP data sets. 2. Validation and first results. Journal of Geophysical Research 100, 1167-1197.

Sheu, G. R., Mason, R. P., 2004. An examination of the oxidation of elemental mercury in the presence of halide surfaces. Journal of Atmospheric Chemistry 48, $107-130$. 
St. Louis, V. L., Rudd, J. W. M., Kelly, C. A., Barrie, L. A., 1995. Wet deposition of methyl mercury in northwestern Ontario compared to other geographic locations. Water, Air, and Soil Pollution 80, 405!414.

St. Louis, V. L., Rudd, J. W. M., Kelly, C. A., Hall, B. D., Rolfhus, K. R., Scott, K., Lindberg, S. E., Dong, W., 2001. Importance of the forest canopy to fluxes of methylmercury and total mercury to boreal ecosystems. Environmental Science \& Technology 35, 3089!3098.

St. Louis, V. L., Sharp, M. J., Steffen, A., May, A., Barker, J., Kirk, J. L., Kelly, D. J. A., Arnott, S. E., Keatley, B., Smol, J. P., 2005. Some sources and sinks of monomethyl and inorganic mercury on Ellesmere Island in the Canadian High Arctic. Environmental Science \& Technology 39, 2686-2701.

Weber, J. H., 1993. Review of possible paths for abiotic methylation of mercury(II) in the aquatic environment. Chemosphere 26, 2063!2077.

\section{Figure captions}

Figure 1. Relation between mean concentrations of $\mathrm{MMHg}$ and reactive $\mathrm{Hg}\left(\mathrm{Hg}_{\mathrm{R}}\right)$ in wet deposition at locations in North America: closed circle, rain in Washington state (Bloom and Watras, 1989); closed triangle up, Maryland rain and snow (Mason et al., 1997); closed triangle down, Connecticut rain and snow (Balcom et al., 2004); open circle, Wisconsin snow (Bloom and Watras, 1989); open square, Wisconsin snow (Lamborg et al., 1995); open triangle up, Wisconsin snow (Fitzgerald et al., 
1991); open triangle down, Wisconsin rain (Lamborg et al., 1995); open diamond, snow in Washington state (Bloom and Watras, 1989).

Figure 2. MMHg versus total Hg in wet deposition at locations in North America: closed circle, rain in Washington state (Bloom and Watras, 1989); closed square, northwest Ontario rain and snow (St. Louis et al., 2001); closed triangle up, Maryland rain and snow (Mason et al., 1997); closed triangle down, Connecticut rain and snow (Balcom et al., 2004); closed diamond, northwest Ontario rain (St. Louis et al., 1995); closed hexagon, northwest Ontario snow (St. Louis et al., 1995); open circle, Wisconsin snow (Bloom and Watras, 1989); open square, Wisconsin snow (Lamborg et al., 1995); open triangle up, Wisconsin snow (Fitzgerald et al., 1991); open triangle down, Wisconsin rain (Lamborg et al., 1995); open hexagon, Ellesmere Island snow (St. Louis et al., 2005). 
Figure 1.

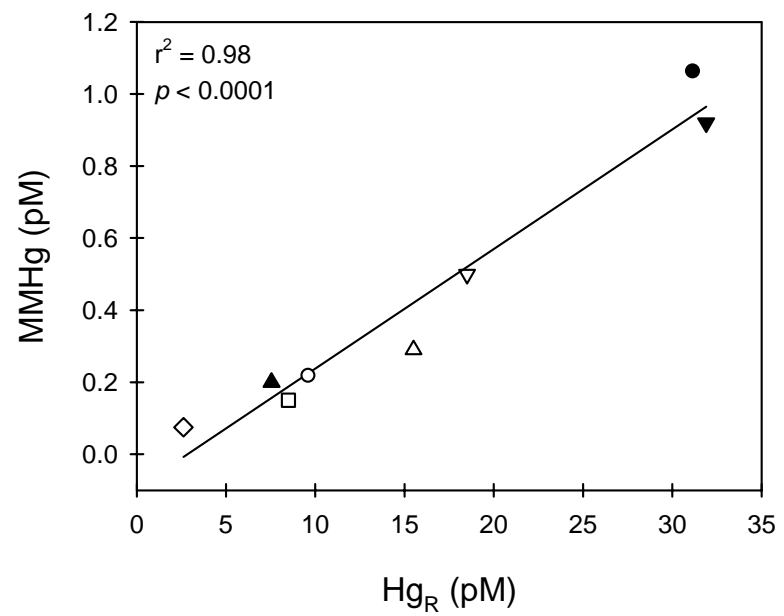

Figure 2.

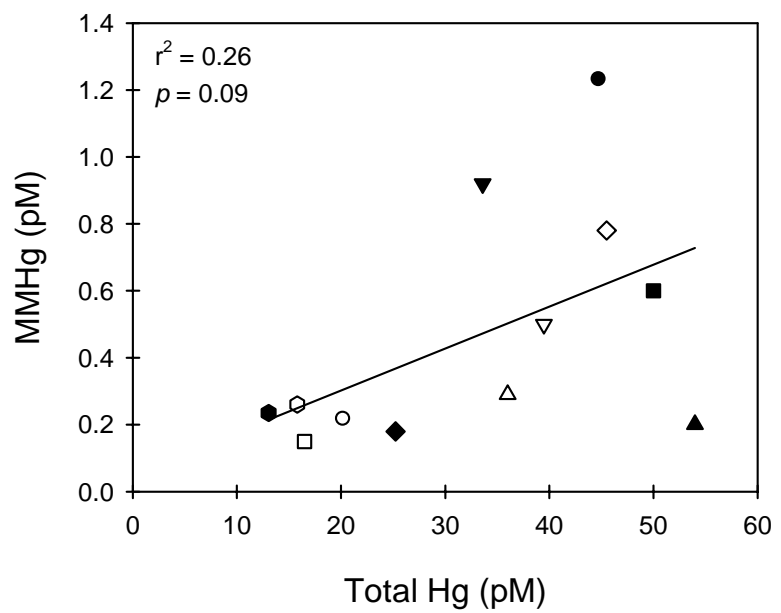


Table 1. Monomethylmercury (MMHg), reactive $\mathrm{Hg}\left(\mathrm{Hg}_{\mathrm{R}}\right)$, and total $\mathrm{Hg}\left(\mathrm{Hg}_{\mathrm{T}}\right)$ in precipitation samples examined in this study.

Values in parentheses are \pm 1 SD of the mean.

\begin{tabular}{lcccccc}
\hline Sample, location & MMHg (pM) & $\mathrm{Hg}_{\mathrm{R}}(\mathrm{pM})$ & $\mathrm{Hg}_{\mathrm{T}}(\mathrm{pM})$ & $\mathrm{Hg}_{\mathrm{R}}: \mathrm{Hg}_{\mathrm{T}}$ & $\mathrm{MMHg}_{\mathrm{Hg}}$ & Reference \\
\hline Rain, Washington state & $1.06(0.60)$ & $31.2(21.8)$ & - & - & 0.034 & Bloom \& Watras (1989) \\
Snow, Washington state & 0.08 & 2.62 & - & - & 0.029 & Bloom \& Watras (1989) \\
Snow, Wisconsin & $0.22(0.08)$ & $9.65(1.30)$ & $20.3(3.45)$ & 0.48 & 0.022 & Bloom \& Watras (1989) \\
Snow, Wisconsin & $0.15(0.15)$ & $8.50(8.50)$ & $16.5(10.5)$ & 0.52 & 0.018 & Lamborg et al. (1995) \\
Snow, Wisconsin & $0.29(0.11)$ & $15.5(11.0)$ & $36.0(14.0)$ & 0.43 & 0.019 & Fitzgerald et al. (1991) \\
Rain, Wisconsin & $0.50(0.50)$ & $18.5(19.5)$ & $39.5(34.0)$ & 0.47 & 0.027 & Lamborg et al. (1995) \\
Rain \& snow, NW Ontario & $0.60(0.30)$ & - & $50.0(35.0)$ & - & - & St. Louis et al. (2001) \\
Rain, NW Ontario & $0.18(0.12)$ & - & $25.2(14.9)$ & - & - & St. Louis et al. (1995) \\
Snow, NW Ontario & $0.24(0.30)$ & - & $13.1(6.3)$ & - & - & St. Louis et al. (1995) \\
Snow, Ellesmere Island & $0.26(0.10)$ & - & $15.8(15.5)$ & - & - & St. Louis et al. (2005) \\
Rain \& snow, Maryland & $0.20(0.21)$ & $7.55(6.50)$ & 54.0 & 0.14 & 0.026 & Mason et al. (1997) \\
Rain \& snow, Connecticut & $0.92(0.26)$ & $31.9(8.70)$ & $33.6(9.2)$ & 0.95 & 0.029 & Balcom et al. (2004) \\
Rain, equatorial Pacific & $<0.05^{\mathrm{a}}$ & $8.9(4.5)$ & $14.4(6.5)$ & 0.62 & $<0.006$ & Mason et al. (1992) \\
Rain, equatorial Atlantic & $<0.04^{\mathrm{b}}$ & $20.2(24.9)$ & $22.9(12.1)$ & 0.88 & $<0.002$ & Lamborg et al. (1999) \\
\hline
\end{tabular}

all samples had less than the detection limit of $0.05 \mathrm{pM}$.

${ }^{\mathrm{b}}$ Only one $(0.095 \mathrm{pM})$ of five samples had more than the detection limit of $0.035 \mathrm{pM}$.

${ }^{\mathrm{c}}$ Average $\mathrm{MMHg}: \mathrm{Hg}_{\mathrm{R}}$ ratio in continental precipitation; excludes the two ocean rain studies. 